\title{
Sr isotopes in glacial melting waters from glaciers in the Konsfjorden area (Svalbard)
}

\author{
MATTEO SALVADORI, ILARIA BANESCHI, \\ MADDALENA PENNISI, MARCO DOVERI, MATTEO \\ LELLI, BRUNELLA RACO, ENRICO CALVI AND SANDRA \\ TRIFIRÒ
}

CNR-IGG

Presenting Author: i.baneschi@igg.cnr.it

In the Kongsfjorden area (W Svalbard), each year a network of glacio-drainage system develops and remains active in the period June-September as a consequence of glacier melting. To trace source and processes of melting dynamic, in June 2018 we performed a field campaign (supported by the Italian base) collecting water samples from Kongsvegen (KGV), Austre $(\mathrm{ABG})$ and Vestre Brøggerbreen (VBG), and Midtre Lovénbreen (MLB) glaciers. On each glacier, sampling sites were selected to be representative of the water flow both of minor drainages produced at different elevations, and of main stream that from proglacial areas enters the Kongsfjorden.

Here, we present the first dataset on isotopic composition of strontium in melting waters. Physico-chemical parameters and water chemistry were determined as well as oxygen and hydrogen stable isotopes.

Samples from KGV, MLB and ABG collected at relative higher elevation have low electrical conductivity (CE) values, ranging between $20-80 \mu \mathrm{S} / \mathrm{cm}$; in these waters the ${ }^{87} \mathrm{Sr} /{ }^{86} \mathrm{Sr}$ ratio is $0.73378,0.73655$ and 0.71392 , respectively. In the three glaciers the increase of EC (up to about $160 \mu \mathrm{S} / \mathrm{cm}$ ), and of $\mathrm{Cl}$, $\mathrm{SO}_{4}$ and $\mathrm{Na}$ is generally associated to a decrease in the isotopic signature of $\mathrm{Sr}(0.71558,0.71164,0.70988$ minimum values for $\mathrm{KGV}, \mathrm{MLB}$, and $\mathrm{ABG}$, respectively), and an increase of $\delta^{18} \mathrm{O}$ (from -12.5 to $-10.5 \%$ vs. V-SMOW). The Sr isotopes behavior is particularly evident in the transect performed at $\mathrm{KGV}$. Conversely, the ${ }^{87} \mathrm{Sr} /{ }^{86} \mathrm{Sr}$ ratios in VBG samples are less radiogenic, and in the range $0.71555-0.70938$.

First results from samples collected in June 2018 indicates that in the drainage system here investigated waters acquire $\mathrm{Sr}$ from crystalline lithologies at $\mathrm{KGV}, \mathrm{ABG}$ and $\mathrm{MLB}$, and from a mixed carbonate+silicate facies at VBG, during the interactions with moraines. The lithologic signature highlighted by $\mathrm{Sr}$ isotopes appears in general subordinated to the marine aerosol component, and it indicates low chemical weathering processes. Hence, our preliminary study could suggest the role played by dry deposition of marine origin in the Kongsfjorden area, as reported in the literatures (i.e.[1-2]).

1.Udisti et al. 2016. Rend. Fis. Acc. Lincei: S85-S94

2.Jacobi et al. 2019. Atmos. Chem. Phys., 19, 10361-10377 